\title{
Detecting spatio-temporal dynamics of urban growth and sprawl through geospatial technique and spectral indicators on Habra-I and Habra-II blocks of North 24 Parganas, India
}

BIJAY HALDER ( $\sim$ halder06bijay@gmail.com )

Vidyasagar University https://orcid.org/0000-0002-4279-5214

Jatisankar Bandyopadhyay

Vidyasagar University

\section{Research Article}

Keywords: Land use/land cover change, Urban sprawl, Spectral Indicator, Shannon's entropy, Geospatial technology

Posted Date: December 21st, 2021

DOI: https://doi.org/10.21203/rs.3.rs-1150767/v1

License: @ (1) This work is licensed under a Creative Commons Attribution 4.0 International License. Read Full License 


\section{Abstract}

The worldwide fertility rate is becoming a most significant context of anthropological condition. Rapid population pressure is one of increasing factors for the global land crisis and gradually affects the environment and boosting climatic vulnerability. But world population progressively increased and hammering the natural environmental condition. Urban heat island (UHI) is increased due to anthropogenic activities and urban expansion, which causes public health emergency. Space-based UHI identification methods are used to estimate the environmental degradation using Land surface temperature (LST) along with different spectral indicators derived from multi-temporal Landsat images. The Landsat imageries were used to calculated land use and land cover maps of 1990, 2000, 2010, and 2020 were used for Habra-I and Habra-II blocks of North 24 Parganas. A supervised classification technique was applied for LU/LC classification.

Shannon's entropy model has been used for detecting urban expansion over the last 30 years. Land use and land cover (LULC) changes are notified in this study region because of urban expansion. $17.81 \mathrm{Sq} . \mathrm{km}$ of Agricultural land and $17.99 \mathrm{Sq}, \mathrm{km}$ of thick vegetation have been decreased similarly 43.24 Sq.km of the built-up area increased. Central Business District (CBD) is more densely population rather than the peripheral part. In the last thirty years around $6.52^{\circ} \mathrm{C}$ temperatures have been increased in this area. The highest values of NDBI are 0.16 (1990) to 0.59 (2020) respectively. The highest values of NDVI are 0.808 (1990) to 0.459 (2020) respectively. That spectral indicator shows that vegetated area has been affected due to urban expansion.

\section{Introduction}

The beginning of twentieth-century great scientific inventions got a new engine like a steam engine, which boosted the process of industrialization. After the Second World War urbanization procedure has totally entered a new development phase where economic development has strongly clinched sub-urbanization. In the developing countries of urban expansion happen in the metropolitan region. Mainly the rapid growth of the population due to rural to urban migration, industries, commercial progress and the housing use higher than the city to the periphery area. The rapid growth of the population results in uncontrolled expansion of settlement. Land is basically a very essential part of human life as well as the main part. In this current time, population expansion, progress in mortality rate (7.1 per thousand deaths), life expectancy rate (67.1 years in India) and sex ratio (940/ thousand) put huge pressure on land. According to the 2011 census of India to total 17.57 (2001-2011 census) corers population was increased. Due to this overloaded population increased problem, land use very much changed. In India 30 percent urbanization process was increase in last 50 years (2011 census). Rapid urbanization, industrialization and technologically build-up area created more land scarcity in worldwide. Many administrative authorities extended the urban area due to extreme population or people migrant another parts of some area. The overwhelming population has been migrated towards those areas because of health facility, transport accessibility and low land value rather than Kolkata.

The rapid growth of the urban areas has been created a huge amount of land cover change and triggered the expansion of peripheral parts of an area; this is known as urban sprawl (Fang et al. 2005; Sarvestani et al. 2011; Aithal and Ramachandra 2016). The results of urban sprawl are overwhelming outward expansion, low population density, poor quality of environment, rapid land use/land cover change, rural area decreased and reduced the vegetated land and agricultural land, random growth with increased land consumption (Sahani and Raghavaswamy 2018; Vani and Prasad 2020). Also, urban sprawl is generated by urban-related problems, like poor quality of drinking water, deprived economic condition, sanitation problem, food scarcity, and increased the health-related problem to the people who are living in the slums area and fringe region (Weber and Puissant 2003; Punia and Singh 2012). The urban sprawl typologies acknowledged are urban fringe, scattered growth, edge expansion, and ribbon development (Wu et al. 2016; Sahana et al. 2018; Fei and Zhao 2019). The urban sprawl is negatively affected the sustainable development of the city, like decreased the eco-environmental condition, increased the daily energy demand due to population pressure and industrialization, and disconnects workplace and residence and the lower housing affordability due to high land value (Chatterjee et al. 2016, Dadashpoor and Salarian 2020). The other signs of urban sprawl are the development of built-up land (Ji et al. 2006), high land value (Frenkel and Ashkenazi 2008), increase of private vehicles (Morollon et al. 2016), low quality of life (Alsharif and Pradhan 2014) and damage the natural land cover area (Sisodia et al. 2018). The Habra-I and HabraII blocks of North 24 parganas were used for this study because of that area were more urbanized in some decades and urban development is hammering the environmental degradation. Urban expansion increased the heat stress related problem, vegetation degradation, air pollution and public health related problem. The two municipalities of the two blocks were shown huge amount of urban development and built-up expansion over some last decades. The peripheral parts of megacity Kolkata is developed the urban area but negative impact also shown like, land use and land cover change, land surface temperature increased, vegetation condition, losses of agricultural land and many others environmental condition.

The urban sprawl is also called the suburban sprawl, which is a rapid geographic extension of the cities or the towns. Due to population pressure and migration towards rural to urban, which is increased the urban sprawl and resulting in land degradation. People were migrated because of economic condition, transportation accessibility, and improve their health but the result in different and increased the health 
related problem and environmental degradation over the slum and fringe area. Sprawling measurement is a more impressive research topic for researchers and scientists to delineating urban planning (Inostroza et al. 2013; Dadras et al. 2015; Fertner et al. 2016; Ozturk 2017; Mosammam et al. 2017; Shukla and Jain 2019; Chettry and Surawar 2020). The urban sprawl is a study that measures the expansion of the built-up area over the urban location associated with concluding the trend, pattern, and extent not only for the urban sprawling phenomena but also for the connected with complications (Sudhira et al. 2004; Jat et al. 2008; Verzora and Gonzalez 2010). The study area was link to the state (West Bengal) capital Kolkata and other important cities and location for goods supply and industrial belts were improved gradually due to urban expansion and population demands. The main occupations were agriculture, fishery and small scale business, which was build their socio-economic improvement (http://www.habramunicipality.com/). Due to urban expansion and infrastructural development of this study area West Bengal, Department if Urban Development and Municipal Affairs (http://www.wburbanservices.gov.in/) were adopted some strategies for development over the study area. Road connection, urban amenities centre, parks, hospital, hearth centres, housing for all schemes, gardens and many others essential aspect for overall development of the study area.

The land use and land cover change dynamics analysis in the field of urban-related studies by the researchers is increasing by investigating the urban growth-related phenomenon (El-Kawy et al. 2010; Sandhya Kiran and Joshi 2013; Rawat and Kumar 2015; Patra et al. 2018; Shooshtari et al. 2020). Due to urban expansion and population pressure urban areas increased the heat and this reason has been increased the chance of Urban Heat Island (UHI). Land surface temperature study is mostly acceptable for urban temperature mapping and monitoring (Gazi \& Mondal. 2018; Ramaiah et al 2020). Different satellite images (thermal band) and notified formulas were used to calculate the LST on this study region on the multitemporal time scale (Rahman et al 2020). Remote sensing and Geographic Information System (GIS) is a powerful technique for monitoring and measuring the land use and land cover change dynamic studies using high resolution of temporal satellite images which is low-cost efficiency than the uses of traditional methods (Bhatta et al. 2010; Belal and Mangham 2011; Kadihm et al. 2016; Srivastava et al. 2017; Mohan Rajan et al. 2020). Urban planners and stakeholders need modern and cost-effective methods and techniques for managing and monitoring urban growth studies using land use and land cover change analysis (Alpopi et al. 2011). Shannon's entropy is an advantageous procedure for studying the computing, mapping, assessing, and monitoring the physical development of urban built-up areas on the neighboring region of the core town (Verzosa and Gongzalez 2010; Dhali et al. 2019; Kumar et al. 2020).

The main focus of this study is (1) Land use and land cover change over 1990-2020, (2) Land surface temperature (LST) calculation of various time interval, (3) Spectral indicator analysis and estimated the relationship with LST and various spectral indicator derived from satellite imageries, (4) Urban sprawl calculation using Shannon's entropy model, (5) calculate the urban expansion over Habra I and Habra II block of North 24 Parganas district, West Bengal, India and (6) Urban Heat Island (UHI) study over the study area. Population pressure is triggering the urban expansion and develops the land also agricultural land and the vegetated area has been converted into the urban area in this study region. This study is to help out to understanding the trend and pattern of manifestation of urban development over the urban space. Also, this research is helpful for urban planners, developers, and stakeholders in the future to build sustainable development and healthy livelihood for the people of this area.

\section{Study Area}

Population pressure, urbanization, and industrial works have been increased and damage the natural environment like; land use and land cover change increased land surface temperature (LST), decreased urban greening, and affected air quality. This study area is located in the West Bengal district, the state of India. The North 24 Parganas district is a part of West Bengal state, which is situated in the southern part of this state. The Sundarban tiger reserve is located in the southern parts of the North 24 Parganas district. The study area is situated into two blocks of North 24 Parganas, named Habra block I and II. The Kolkata and Howrah municipality is the nearest urban area, due to transportation accessibility, health facility, urban amenities, and overwhelming population pressure, this area is converted into urban agglomeration. Two municipalities are included in this study area, named Habra and Ashokenagar Kalyangarh Municipality. The total study area was around 251 sq.km and Habra and Ashokenagar Kalyangarh Municipality are sharing their boundary in eastern parts (Fig. 1).

The total study area is situated into $88^{\circ} 32^{\prime}$ - $88^{\circ} 48^{\prime}$ east longitude to $22^{\circ} 46^{\prime}-22^{\circ} 56^{\prime}$ North latitude with an average elevation is $13 \mathrm{~m}$ (42 feet). Habra municipality is situated within Habra Police Station which is a part of Barasat Sub-Division. The municipality was established in the year of 1979 and initially, nineteen wards have divided this municipality. Habra-I and Habra-II blocks of North 24 Parganas are covered 148 Sq.km and 133 Sq.km respectively. At the established time population of Habra municipality was approximately 72500 people and currently, this municipality has a $21.82 \mathrm{sq.km}$ of total area and around 147221 population (Census of India, 2011)( http://www.habramunicipality.com/). Ashokenagar Kalyangarh Municipality is also a densely populated with 20.50 sq.km area and 23

Page 3/23 
wards. The population of this municipality is 121592, as per Census of India (https://censusindia.gov.in/). The population pressure is increased the urbanization process and affected the natural environment. Increased land surface temperature, vegetation degradation, LULC change and increased the urban heat island. The urbanization trends and pattern analysis are helpful for future urban planning with the suitable modification. This study is also helpful for urban planner and decision maker for future sustainable development of those two municipalities.

\section{Materials And Methods}

The urban expansion of this study area affecting the land use and land cover change. This study is focused on the urban expansion scenario, identifying the changing pattern, quantifying and interpreting overall land use/land cover change and build-up growth based on the Landsat Thematic Mapper (TM), Landsat Operational Land Imager (OLI) and field observation over the study area (Fig. 2).

\subsection{Data Source}

In the data for study area, land use and land cover change established using Landsat image. Different year image were using to identify the actual change scenario for earth surface (https://earthexplorer.usgs.gov/) with the least clouds and snow cover $<10 \% .199,2000,2010$ and 2020 year images were taken for land use/land cover change detection and detect the urban sprawl over the area. For the well understanding the urban sprawl of this area 2020 satellite image was deliberately included in this area despite a difference in the time interval. The selected satellite imageries information was shown in the Table 1. The Population data, administrative boundary and total urban agglomeration area of this study area were derived from Census of India (https://censusindia.gov.in/). Supervised classification and maximum likelihood algorithm is used to classified the satellite images and delineation of the urban sprawl over the study area.

\subsection{Image processing phase}

The satellite images were pre-processed to detect the built-up expansion of the study area for the year of $1990,2000,2010$ and 2020 . With the minimal alteration of the geometric accuracy the satellite imageries were collected from different dates. To development the satellite images quality; data were enhanced using histogram equalization (Meshesha et al. 2016). Rectification is necessary for eliminate the image distortion. To eliminate the image distortion images were projected into World Geodetic System (WGS) 1984 Universal Transverse Mercator (UTM) zone 45 N. Data are pre-processed in ERDAS IMAGINE v14 and geo-referenced, atmospheric correction, radiometric correction and finally subsisting Region of Interest (ROI). The ArcGIS v10.5was used for map layout and data preparation, LST calculation using raster calculation tool, UHI calculation and correlation analysis.

\subsection{LULC classification and accuracy assessment}

Land cover is the natural earth surface features which is develop by naturally, like vegetation coverage, water bodies, agricultural land, etc. the land use and land cover change analysis is more important to identifying the urban expansion along with the urban sprawling over the study area using different time periods (Ramachandra et al. 2013; Bharath et al. 2017). The urbanization processes, population pressure and industrialization were hammering the natural land cover area and affecting the vegetation cover, agricultural land, etc. The supervised classification approach with the maximum likelihood algorithm was used to identifying the land use/land cover change analysis using different year Landsat images to conduct multitemporal LULC classification (Singh et al. 2017). The area were classified into five classes like, built-up area, vegetation cover, agricultural land, water body and open spaces over this study area.

The post-classification stage is used to increase the LULC classification accuracy (Cheruto et al. 2016) Using different years satellite images, medium-spatial resolution of Landsat data (TM and OLI) mixed pixels are a common problem (Lu and Weng 2005), mainly the urban areas are heterogeneous mixtures including a residential area, roads, railway, soil, trees, water, and grassland (Jensen et al. 2007). Remote sensing software (ERDAS IMAGINE v14 and ArcGIS v10.5) is used for the accuracy assessment. Accuracy assessment is a technique, which represents the correspondence between the aspect of earth surface and results of the classification. It is very important to detect the perfect accuracy by the proper classification of different year satellite imageries to analyse the land-use changes (Owojori and Xie 2005). The accuracy assessment of the land use and land cover maps were checked using the ground truth data and the results were interpreted using overall accuracy (OA) and kappa coefficient $\left(\mathrm{k}_{\mathrm{i}}\right)($ Table 3$)$, which is shown in the equation 1 and 2.

$O A=\left(\frac{\sum_{i=1}^{k} n_{i j}}{n}\right)$ Eq. 1 
$K_{i}=\frac{\text { (Observedaccuracy }- \text { Chanceaccuracy) }}{(1-\text { Chanceaccuracy })}$ Eq. 2

Where, $n_{i j}$ is representing the diagonal elements in the error matrix, $k$ is total number of classes in the LULC classification, $n$ is total number of samples in the error matrix and $\mathrm{K}_{\mathrm{i}}$ representing the kappa coefficient.

\subsection{Land use and Land Cover Change}

A post-classification change detection technique was calculated in ERDAS Imagine. Many researchers were used to detect the actual change of the urban environmental area or natural location and rate of change (Hardin et al. 2007). The change detection was calculated in pixel by pixel basis and a new thematic layer was created using five class maps, containing different combination of 'from-to' change classes (Hassan et al. 2016)(Table 2).

\subsection{Shannon's entropy model}

Land use and land cover (LULC) dynamic study is more essential for anthropological effect assessment and climate change impact. But LULC is not sufficient to estimate the change analysis, trend, and pattern of physical growth of and urban areas. Therefore, intensity and level of change in urban areas are most essential for physical growth analysis of the urban areas. Shannon's entropy model was used for this study for generating the spatial concentration and dispersion in an urban environment (Tewolde and Cabral 2011). Many researchers have been used this method to measure the urban sprawl with help of the Geographic Information System (GIS) (Verzosa and Gongzalez 2010; Dhali et al. 2019; Kumar et al. 2020). Shannon's entropy model is also specifying the degree of urban expansion by investigating whether the land development is dispersed or compact (Lata et al. 2001). The literature review is also indicating that Shannon's entropy model is a mostly used technique to identifying urban expansion.

Shannon's entropy $(\mathrm{H})$ model is used to detecting the degree of spatial absorption or diffusion of a geographical variable (Xi) between different zones (Thomas 1981). The entropy model has calculated this following formula (Eq. 3).

$$
H_{n}=\sum_{i=1}^{n} P_{i} \log _{e}\left(\frac{1}{P i}\right) \text { Eq. } 3
$$

Where, $\mathrm{P}_{\mathrm{i}}$ indicates the proportion of phenomenon occurring in the ith zone $\left(P_{i}=\frac{X_{i}}{\sum_{i=1}^{n} X_{i}}\right), X_{i}$ is the observed value occurring in the ith zone. $\mathrm{n}$ denote the total number of zones. The value range of entropy model is from 0 to $\log _{e}(n)$. 0 value is indicate that the urban built-up area is vary compact where $\log _{e}(n)$ denote that the built-up area distribution is dispersed. The scale of relative entropy value is the range of 0 to 1. The relative entropy $\left(\mathrm{H}^{1}\right)$ for $n$ number of zones can be calculated in this formula (Eq. 4)

$H_{n}^{1}=\frac{H_{n}}{\log _{e}(n)}$ Eq. 4

Where $\mathrm{n}$ denote the number of zones for urban sprawling study.

Shannon's entropy model is used for urban sprawl study and this method is used by various aspect like buffer zone wise (Yeh and Li et al. 2001; Sudhira et al. 2004; Sun et al. 2007; Mosammam et al. 2017; Dhali et al. 2019), Direction-wise techniques (Alsharif et al. 2015; Ozturk 2017) and ward-wise (Jat et al. 2008; Punia and Singh 2012). In this study, direction based Shannon's entropy model has been used to estimate the urban expansion over two municipality of Habra-I and Habra-ll block, West Bengal, India. The CBD location is identified and then eight direction are establish for calculating the urban sprawling area that is N: North, NE: North-east, E: East, SE: Southeast,S: South, SW: South-west, W: West and NW: Northwest).

\subsection{Buffer zone formation}

The Central Business District (CBD) area has been detected from the field visit. The CBD of two municipalities is the Rail Gate 2 area, which is the joint road of Highway 112 (Barasat-Petrapole Road) and Jirat road. Barasat-Petrapole Road and Jirat road are then named Jessore road. To measure the urban expansion six buffer zones are created from the CBD area. The buffer zones are $1 \mathrm{~km}, 2 \mathrm{~km}, 3 \mathrm{~km}, 4 \mathrm{~km}, 5 \mathrm{~km}$, and $6.5 \mathrm{~km}$ from the CBD area. Built-up densities are calculated from each buffer zones to estimate the urban expansion of each year from 1990-2020.

\subsection{LST calculation}

Page 5/23 


\subsubsection{LST for Landsat TM}

The LST is calculating by this established formula. Supported Ca et al (2008), to estimated brightness temperature a two-stop process are followed from Landsat TM images. The equation is that.

1. Conversion of the digital number (DN) to spectral radiance (L) (USGS 2001) is calculated by Eq. 5.

$L=\left(\frac{L_{\max -L_{\min }}}{D N_{\max }}\right) \times$ Band $+L_{\min }$ Eq. 5

Where $L$ is that the spectral radiance, $L$ min is that the 1.238 (Spectral radiance of the DN value 1), Lmax is that the 15.6000 (Spectral radiance of $D N$ value 255$)$, and $D N$ is that the digital number.

2. The spectral radiation was need to conversion of kelvin. To estimate the spectral radiance to temperature in kelvin the notified formula was used for Landsat $5 \mathrm{Tm}$ data. Conversion of spectral radiance to temperature in kelvin (USGS 2001) is calculated by Eq. 6.

$T b=\frac{K 2}{\left(\frac{K 1}{L \lambda}+1\right)}$ Eq. 6

Where, $\mathrm{K} 1$ id the calibration constant 1 (607.76), $\mathrm{K} 2$ is that the calibration constant 2 (1260.56), and $\mathrm{Tb}$ is that the surface temperature (kelvin).

3. Normalized Different Vegetation Index (NDVI) is requiring for land surface temperature (LST) map generation. Calculation of NDVI

$N D V I=\frac{(N I R-R)}{(\mathrm{NIR}+\mathrm{R})} \mathrm{Eq} .7$

Emissivity is mostly important for land surface temperature (LST) calculation and generation of land surface emissivity the notified formula has been used for Landsat 5 TM data. Land surface emissivity (LSE) is calculated based in NDVI values. It used the NDVI Thresholds Method-

NDVITHM by applying the Eq. 8 (Sabrino and Raissouni 2001).

$\mathrm{LSE}=(1.0094+0.047) \times \ln (\mathrm{NDVI})(\mathrm{Eq} .8)$

The NDVI value range from 0.157 to 0.727 . When the NDVI values out of the range $(0.157$ to 0.727$)$, the corresponding input LST constant values are used.

4. Conversion of kelvin to Celsius (Semenza et al. 1996) is estimated by Eq 9.

$\mathrm{LST}=\mathrm{Tb}-273.15$ (Eq. 9)

\subsubsection{LST for Landsat OLI}

1. Conversion of the Digital Number (DN) to spectral radiance (L) (Rasul et al.2015; Scarano et al. 2015) is calculated by Eq. 10.

$L=\left(\frac{L_{\max }-L_{\min }}{D N_{\max }}\right) \times$ Band $+L_{\text {min }}$ (Eq. 10)

Where

$\mathrm{L}=$ Atmospheric spectral radiance $(\mathrm{SR})$ in watts $/\left(\mathrm{m}^{2 \star} \mathrm{srad}^{\star} \mu \mathrm{m}\right)$,

$\mathrm{L}_{\max }=$ Maximum spectral radiance (SR) of the $\mathrm{DN}$ value

BandL $_{\min }=$ Minimum spectral radiance (SR) of Band

$\mathrm{DN}_{\max }=\mathrm{Q}_{\text {cal max }}-\mathrm{Q}_{\text {cal min }}=$ maximum and minimum difference of sensor calibreation

2. Using the thermal constants given in the metadata file, the TIRS band data has converted from SR to BT once the DN value are converted to SR (Gutman et al 2013) (Eq. 11). 
$B T=\frac{K 2}{\operatorname{Ln}\left(\frac{K 1}{L \lambda}+1\right)}-273.15($ Eq. 11)

Where,

$\mathrm{K}_{2}$ and $\mathrm{K}_{1}$ represents the band-specific thermal conversion constants,

BT = Brightness temperature in Celsius.

3. Calculation of NDVI (Roy et al. 2014; Halder et al. 2021) (Eq. 12):

$N D V I=\frac{(N I R-R)}{(\mathrm{NIR}+\mathrm{R})}($ Eq. 12$)$

Where, the Range between: $-1<\mathrm{NDVI}<+1$.

4. Proportion of Vegetation is calculated by minimum and maximum NDVI value (Yu et al. 2014). TheEquation is (Eq. 13)

$P v=\left(\backslash \operatorname{frac}\left\{\backslash \operatorname{text}\{\mathrm{N}\} \backslash \operatorname{text}\{\mathrm{D}\} \backslash \operatorname{text}\{\mathrm{V}\} \backslash \operatorname{text}\{\mid\}-\{\mathrm{NDVI}\}_{-}\{\min \}\right\}\left\{\{\mathrm{NDVI}\}_{-}\{\max \}-\{\mathrm{NDVI}\}_{-}\{\min \}\right\}\right)^{2}$ Eq. 13

5. Land surface emissivity (LSE) is calculated based $P_{V}$ Value. It used the NDVI Thresholds Method- NDVITHM by applying the Eq. 13 (Roy et al. 2014; Avdan et al. 2016).

LSE $=0.004 \backslash$ times Pv+0.986 Eq. 14

6. Conversion of kelvin to Celsius (Roy et al. 2014; Yu et al. 2014; Avdan et al. 2016) is estimated by Eq. 15

$\mathrm{LST}=\backslash \operatorname{frac}\{\mathrm{BT}\}\{\backslash\{1+\backslash \operatorname{left}[\backslash \operatorname{frac}\{\{\backslash$ lambda $\} \backslash \operatorname{text}\{\mathrm{B}\} \backslash \operatorname{text}\{T\}\}\{\{\backslash$ rho $\}\} \backslash \operatorname{right}] \backslash \operatorname{text}\{\mid\} \backslash \operatorname{text}\{\mathrm{n}\}(\backslash \operatorname{text}\{L\} \backslash \operatorname{text}\{S\} \backslash \operatorname{text}\{\mathrm{E}\})\}(\operatorname{Eq} .15)$

Where

$\lambda=$ the wavelength of emitted radiance.

\subsection{Different Spectral Indicator}

\subsubsection{Normalized Difference Vegetation Index (NDVI)}

Normalized Difference Vegetation Index (NDVI) is used to classify of the vegetation cover on the earth surface and experiment the area is under urban vegetation or not, using remote sensing satellite data (Weng and Lo 2001). NDVI is signifying the vegetation development of the earth surface which is retaining by the local climate variable like precipitation (Xiao and Weng 2007). The NDVI value is positioned in -1 to +1 , values around 0 is demonstrating the area under poor vegetated area such as barren land; built-up land and many others land classes. The values close to the plus one $(+1)$ is signify the healthy vegetation and forest cover area all through near minus one $(-1)$ shows water body area of the study location. The Normalized Difference Vegetation Index or NDVI equation is (Eq. 16)

NDVI=\left } ( \backslash \text { frac } \{ \text { NIR-Red } \} \{ N I R + R e d \} \backslash \text { right } ) \text { Eq. } 1 6

\subsubsection{Normalized Difference Built-up Index (NDBI)}

Normalized Difference Built-up Index (NDBI) is calculated for the urban area identification where Landsat 5 (Thematic Mapper) TM and 8 OLI (Operational Land Imager) shortwave infrared (SWIR) is characteristically higher reflectance compared to the near-infrared region. This built-up index (Eq. 17) is used for built-up area and land use planning (Lu and Weng 2006).

$N D B I=\frac{(S W I R-N I R)}{(\text { SWIR }+ \text { NIR })} \quad($ Eq. 17$)$

$\mathrm{NDBI}$ is describe that the value between -1.0 to +1.0 . Built-up area is detected in Normalized Difference Built-up Index (NDBI) values are that the positive values are shown.

\subsection{Validation of the result}

To validate the results of this study, Google Earth and field visit data are used to identifying the various land use land cover classes. Different year's satellite imageries are classified in ArcGIS v10.5 and ERDAS IMAGINE v14 using supervised classification method with maximum likelihood algorithm. A field visit is helping out for the road, educational institute, administrative, markets, commercial place, and 
many other urban amenities. These urban amenities have triggered the attraction of the population and boosting the process of urbanization over the study area. The Google Earth and field visit can help to identify the appropriate results and validation of this study.

\section{Result And Discussion}

\subsection{Land Use and Land Cover Map}

Red, Green and blue colour band combination of the four different year satellite imageries were used for classification using standard colour combination. Landsat 5 TM and Landsat 8 OLI/TIRS all bands were combine in erdas imagine software in 'Layer Staking' toolbar. Population pressure has been increased the food and residential area demand over the world and this population pressure was increased the urban expansion and infrastructural development, which was negatively impact over the society. After the urban expansion of this area, in between the central part of this study area observed huge land use change. Basically there was handling of population pressure, Build-up area was rapidly increased and vegetation area was decreased similarly. The Land use and Land cover change dynamics was calculated in the years of 1990 to 2020 (Fig. 3). After expansion of urbanization, transportation system is very good for local people. Land value was increased and living sustainably upgrading day by day.

\subsection{Land Use and Land Cover Change Dynamics}

In the land use and land cover classification, supervised classification techniques with maximum likelihood algorithm have been used for the years 1990, 2000, 2010, and 2020. Seven types of land classes were identified for four different years LULC maps, which are water bodies, wetland, open space, grassland, thick vegetation, agricultural land, and built-up land. Thick vegetation and agricultural land have been decreased on overall Habra-I and Habra-II blocks. The Thick vegetation areas are 34.07\% (1990), 32.76\% (2000), 31.33\% (2010), and $27.66 \%$ (2020), where 17.99 Sq.km of thick vegetation has been decreased during the thirty years (Table 4). In the difference of area where thick vegetation has been increased in the year of 17.99 Sq.km rather than the grassland area is decreased in 6.15 Sq.km (2000), 5.59 Sq.km(2010), and 4.81 Sq.km(2020) respectively (Table 4-5). Vegetation area is decreased due to urbanization, basically residential needs. Land transformation is more effected on this area, Habra and Ashokenagar Kalyangarh municipalities are more built-up areas. Agriculture is the main occupation of this location but a huge amount of land transformation is affected by this natural phenomenon. This case is the reason for primary economic activities are converted into secondary and tertiary economic activities because of residential land, recreational land, and migration for occupation. The anthropogenic activates are much affected by the land use and land cover classes. Land values and quality of land are change regularly. Central parts of these Habra-I and Habra-II blocks are more urban area. Agricultural land is decreased in different years like 142.66 Sq.km (1990), 137.41 Sq.km (2000), 131.24 Sq.km (2010), and 124.85 Sq.km (2020) (Fig. 4) which denote that the agricultural land has been decreased and the percentage of total areas is $50.77 \%(1990), 48.9 \%(2000), 46.71 \%$ (2010) and 44.44\% (2020) (Table 4). Those results show that the agricultural land mostly transforms to other land classes of Habra-I and Habra-II blocks of North 24 Parganas, West Bengal, India. In the initial phase of this study, 1990 map vegetation area was shows that the huge amount but after that the vegetated area has been decreased due to urban expansion, population pressure, industrial works and many others anthropogenic activities. The healthy vegetation increased the oxygen level in atmosphere and control the urban heat island related problem over the study area. Vegetation area also decreased the soil erosion, increased soil moisture and many others think. But after urban expansion and population pressure the Habra area was located huge vegetation deficiency and vegetated land was converted into agricultural land and urban built-up land.

Other land classes like built-up areas are increased due to population pressure, migration to another place, low land values, and near the business city Kolkata. In the year 1990, the built-up land of to block is $10.22 \mathrm{Sq} . \mathrm{km}$ but after that urbanization is targeted the built-up land and increased gradually, which is 18.54 Sq.km (2000), 31.54 Sq.km (2010), and $53.46 \mathrm{Sq} . \mathrm{km}$ (2020). The percentages of built-up lands are $3.64 \%$ (1990), 6.6\% (2000), 11.22\% (2010) and 19.02\% (2020) of entire location. Grassland is increased on this study location around $7.02 \%$ (1990), 6.15\% (2000), 5.59\% (2010) and 4.81\% (2020) area has been identified by the classification maps in different years. The accuracy assessments are $92.90 \%, 92.27 \%, 93.79 \%$, and $94.46 \%$ in the year $1990,2000,2010$, and 2020 . The kappa coefficient are 0.91 (1990), 0.90 (2000), 0.92 (2010) and 0.93 (2020) respectively (Table 8-11). The CBD area is mostly urbanized and other parts of this location have transformed the land into thick vegetation to agricultural land and agricultural land to the built-up area. Population pressure, technology build-up is the main reason for urban expansion and this condition is affected by the natural environmental condition over those two blocks.

\subsection{Land transformation}

Land transformation is the main reason for land use and land cover change. The overall area is decreased open space, thick vegetation, and agricultural land over the thirty years. Gradually built-up land, water bodies, and grassland are increased. Built-up land is increased due to urbanization and population pressure. One open space is located beside the Habra railway station, which name is 'Habra Math' and

Page $8 / 23$ 
many others distributed in many parts of this study area. Many urban amenities like, market, bank, ATM, post office, shopping mall, playground, and restaurants were increased the urbanization in this location. The CBD is located near Habra railway station, which is joint in Kolkata's one of the busiest railway junctions 'Sealdha'. Highway 112 is directly joint the Netaji Subhas International Airport. Near CBD many urban amenities were build-up named, Rupkatha Cinema Hall, Central Bank of India, IndusInd Bank, HDFC Bank, State Bank of India, Habra Rail Bazar, Uco Bank, Radharani Park, Kalika Cinema Hall, and many others.

The land transformation is very high due to urban expansion over Habra-l and Habra-ll blocks of North 24 Parganas. Built-up area is increased around 8.32 Sq.km (1990-2000), 13 Sq.km (2000-2010) 21.92 Sq.km (2010-2020) and total 43.24 Sq.km (1990-2020). The two municipalities' areas are more urbanized. Gradually thick vegetation and agricultural land have been decreased due to urban expansion. The thick vegetation is decreased in the year between 1990-2000, which is 3.68 Sq.km but after that 4.02 Sq.km (2000-2010), 10.29 Sq.km (2010-2020) and overall 17.99 Sq.km of area decreased (1990-2020). Agricultural land is decreased which is notified that 5.25 Sq.km (1990-2000), 6.17 Sq.km (2000-2010), 6.39 Sq.km (2010-2020) and overall 17.81 Sq.km area of agricultural land has been decreased between 1990-2020 (Table 5). Overall 6.19 Sq.km of grassland are decreased and 4.68 Sq.km open space are decreased due to urban expansion (Fig. 5a-d) The maps show that urban expansion was affected the natural environment and many parts of this study area have been converted the agricultural land, thick vegetation, and open space into built-up land due to land demand and population pressure. The built-up land development is used for residential and commercial purposes have been a major impact on urbanization over the study area for thirty years. From this study, urban expansion is the crucial factor for land use land cover transformation. So, LULC planning and management are the major factors for the sustainable livelihood of this area.

\subsection{Analysis of urban growth using Shannon's entropy model}

The Shannon Entropy model is used to identifying the urban growth is compact or discrete one. The built-up area is more affecting part of this location due to urban expansion. The eight quadrants are used to identify the built-up growing over the land use due to high rate of urbanization over the last thirty years (Table 6). The built-up rate is high in North-west (NW); West (W); North-east (NE) and South-East (SE) parts in the year of 1990 (Fig. 6). After that, in the year of 2000, North-East (NE) parts are more built-up expansion. The map of 2020 shows that, South-West (SW); West (W), North-West (NW) is more built-up area located. This areal expansion of urban area designates that whether the municipalities become a sprawled one or not. The entropy values are greater in NW, W, SW, and E direction of two municipalities. The main source of built-up land is located near Habra rail station, highway 112 and urban amenities area. The results shows that the total built-up area expansion the gradually occurring last thirty years and overall Shannon Entropy values are increased in different time intervals. The entropy value does not cross the 0.5 , which is denoted that the municipalities are taking the compact urban growth progressively from 1990 to 2020. Shannon Entropy model is very useful technique to identifying and monitoring the urban expansion and sprawling and also detecting the physical environmental condition. This study is to identify the built-up expansion over two municipalities of Habra-I and Habra-II blocks of North 24 Parganas.

\subsection{Buffer zone wise urban area calculation}

This study is to identifying the built-up expansion over the Habra and Ashokenagar Kalyangarh municipality using six buffer zone and also identifying the LULC change, LST change, Spectral indicator (NDVI and NDBI) change over Habra-I and Habra-II blocks of North 24 Parganas from 1990-2020. The main focus is that built-up expansion over two municipalities. The CBD areas more densely because the residential and commercial areas are a huge amount identified. Like Flats, Market, Shopping Malls, Bank, Park, and many other urban amenities. Also, the road networks are created densely over the CBD area. The 'Habra Railway Market' is a more populated area rather than the peripheral and core part of this study area. The second buffer zone 2 has been named as a core area because the area is the quintessence of central business district (CBD) is left and the actuality of housing area can similarly be seen here (Table 7). Buffer zone 3 is also created because the residential area can be located and the name of this area is the outer core area (Fig. 7). The 4th zone of the buffer is named an urban fringe area because this zone is mixed up with the urban-rural culture. 5th and 6th buffer also created and the names of those buffer zones are Thresholds urban limit area and Periphery area (Fig. 7). The agricultural land is also proved that this area has rural activities like crop production, livestock farming, etc. also rural-urban interaction can be identified clearly.

The results show that the proportion of the built-up area is mostly in CBD which has noticed that 10.88\% (1990), 19.33\% (2000), 42.04\% (2010), and 79.52\% (2020). Also the core areas have 4.25\% (1990), 5.24\% (2000), 36.18\% (2010) and 49.24\% (2020) respectively (Fig. 7). Table 7 shows that the year and the percentage-wise built-up area in different named buffer zones. The peripheral part of this area shows that the negative relationship between built-up area and distance from CBD location due to transportation accessibility, urban amenities, etc. the built-up land density is lower from CBD area to periphery parts of this study location. The homogeneous land structure has increased the chance of more built-up in the CBD area. The periphery part of this study area has been lower opportunities for urbanization and higher diversified land use structure like agricultural land, thick vegetation, etc. The results show that the CBD area more densely urbanized rather than other parts of this area. 


\subsection{LST variation}

Land surface temperature is increased due to urbanization, population pressure, and industrial work. Habra-I and Habra-II blocks of the North 24 Parganas district are the peripheral areas of the Kolkata metropolitan area. High accessibility and business area joint the peripheral part. Habra railway station and highway 112 is directly joining the Kolkata area and Netaji Subhas International Airport area. Those reasons are increased the built-up area also land value is the important factor because in past days the land values are low rather than present days. Those reasons are increased the LST of this study location. In the years 1990 , the high-temperature value is $23.52^{\circ} \mathrm{C}$ and the low temperature is $17.78^{\circ} \mathrm{C}$. Similarly highest temperatures are $25.55^{\circ} \mathrm{C}, 27.19^{\circ} \mathrm{C}$, and $30.04^{\circ} \mathrm{C}$ in the years of 2000 , 2010 , and 2020 respectively. The lowest temperature values are $18.07^{\circ} \mathrm{C}, 19.87^{\circ} \mathrm{C}$, and $22.01^{\circ} \mathrm{C}$ in the years 2000,2010 , and 2020 accordingly (Fig. 8). In between thirty years around $6.52^{\circ} \mathrm{C}$ temperatures were increased due to anthropogenic activities.

\subsection{Spectral Indicators}

Two spectral indicators have been used in this study for identifying the correlation with land surface temperature (LST). Normalized Difference Vegetation Index (NDVI) is used for monitoring the vegetated area and degradation over 1990-2020 on this study area. The central part of Habra is more vegetated in the year 1990 but after that urban expansion is damaged the vegetated area. Also, NDVI maps are used for monitoring the vegetation health over Habra-I and Habra-Il blocks of North 24 Parganas (Fig. 9). The highest value of NDVI is 0.808 but after thirty years the values decreased to 0.459 due to urban growth. Normalized Difference Built-up Index (NDBI) maps are used for monitoring the built-up expansion over this study area. The central part of this area like around the Habra railway station area is densely populated due to high accessibility and urban amenities. The highest value of NDBI is 0.16 in the year 1990 and the highest value of NDBI is 0.59 in the year 2020 respectively (Fig. 10). Those NDBI maps show the perfect variation of urban expansion.

\subsection{Correlation analysis between LST and spectral indicators}

Land surface temperature is the dominating factor for the climate change scenario. In the urban area, due to anthropogenic activities like urbanization, transportation development, and industrialization have increased the LST over an urban location. The urban area has more LST values rather than a rural area. This study location also has both types of land areas. But when correlated with vegetation index and built-up index with LST, the results are very interesting. The correlation with LST and NDVI on this location, results are showing negative. The $\mathrm{R}^{2}$ denoted that $0.23,0.17,0.12$, and 0.07 in the years of $1990,2000,2010$, and 2020 respectively. Due to urbanization, vegetation areas are consistently decreased, and newly developed built-up land on this study area. The correlation between LST and NDBI results were showing positive due to high build-up land. The $\mathrm{R}^{2}$ values show that $0.18,0.26,0.38$, and 0.42 in the years of $1990,2000,2010$, and 2020 accordingly (Fig. 11). These results indicate that vegetated areas decreased and built-up areas increased due to anthropogenic activates and need proper planning for environmental conservation.

\section{Conclusion}

Land use and land cover is the most dominating factor for our environment. This study is to identify the LULC dynamics using satellite remote sensing data over the two municipalities (Habra and Ashokenagar Kalyangarh Municipality) of Habra-I and Habra-II block, West Bengal. The spatial extension of the urban area is also identifying using Shannon's entropy model. Agricultural land and Vegetated area have been degraded due to the rapid growth of built-up areas along with urbanization and transportation accessibility. The built-up area has been extended during the periods of 1990-2000, 2000-2021, and 2010-2020, also most urbanization identifying between the years of 2010-2020. 43.24 Sq.km of built-up area has been expended during the years of 1990-2020 and gradually 17.81 Sq.km and 17.99 Sq.km of agricultural land and thick vegetation has been decreased on Habra-I and Habra-II blocks of North 24 Parganas district of West Bengal. The NDVI maps are showing the vegetation scenarios of this area in the last thirty years. Healthily vegetation located in the year 1990 but due to urbanization, population pressure and transportation decreased the vegetation area. Land surface temperature also increased due to urban expansion over the densely populated area of Habra and Ashokenagar Kalyangarh Municipality. The central parts of this study located experienced a huge amount of temperature fluctuation in the last thirty years. Around $6.52^{\circ} \mathrm{C}$ temperature increased in just thirty years.

The Landsat Tm and OLI/TIRS satellite imageries were used for this study. Urban expansion is the most affecting parts of our environment and increased the environmental degradation over the study area. The urban heat island (UHI) and land surface temperature (LST) were used for this study. Habra-I and Habra-II blocks of North 4 Parganas district were used for this study to identifying the urban sprawl and LULC change detection over the study area. Due to 30 meter resolution, minor level investigation is not properly identifying but the general study has been improved for planning and urban development purpose. The urbanization process has been extended due to population pressure and the development of income. Urbanization is not only the built-up area; it's also the commercial, industrial, and many urban

Page $10 / 23$ 
amenities area. The overwhelming population is the main worry of those areas because of the unplanned development of the urban areas. The nearest metropolitan area Kolkata, the business hub is increased the income source and develop a healthy livelihood. Habra-I and Habra-ll people were travelled towards Kolkata due to their income source. This research is carried out on the urban growth and condition of natural environmental variables over Habra-I and Habra-II blocks of West Bengal state, India. The outcome of this research may support the urban planner and local administrators to realize the past and present trends of urbanization in this area and prepare a proper planning strategy for the future. Urban planners and local administrators can change the improvement of the unplanned development of urbanization and reduce the effect of natural environmental variables.

\section{Declarations}

Acknowledgements: We would like to thank the Vidyasagar University to support this research. We are also thankful to the Local Government body for our field data collection and other necessary secondary data collection. We also express our gratitude to the United States Geological Survey Department for providing freely satellite data.

Conflict of Interest: On behalf of all authors, the corresponding author states that there is no financial or non-financial interest to disclose.

Informed consent All participants provided informed consent ahead of their participation on the research.

Ethical Approval There is no human or animal participate or research in the study. Data is available in the notified website and available software is used for this study. Therefore do not need any ethical approval for this research.

Funding: There is no financial support in this research.

\section{References}

Alpopi, C., Manole, C., \& Colesca, S. E. (2011). Assessment of the sustainable urban development level through the use of indicators of sustainability. Theoretical and Empirical Researches in Urban Management, 6(2), $78-87$.

Abd El-Kawy, O. R., Rød, J. K., Ismail, H. A., \& Suliman, A. S. (2011). Land use and land cover change detection in the western Nile delta of Egypt using remote sensing data. Applied geography, 31(2), 483-494. https://doi.org/10.1016/j.apgeog.2010.10.012

Alsharif, A. A., \& Pradhan, B. (2014). Urban sprawl analysis of Tripoli Metropolitan city (Libya) using remote sensing data and multivariate logistic regression model. Journal of the Indian Society of Remote Sensing, 42(1), 149-163. https://doi.org/10.1007/s12524-013-0299-7

Avdan U \& Jovanovska G. (2016). Algorithm for automated mapping of land surface temperature using LANDSAT 8 satellite data. Journal of Sensors, 2016. Cohen J. (1968). Weighted kappa: nominal scale agreement provision for scaled disagreement or partial credit.

Psychological bulletin, 70(4), 213. https://psycnet.apa.org/doi/10.1037/h0026256

Aithal, B. H., \& Ramachandra, T. V. (2016). Visualization of urban growth pattern in Chennai using geoinformatics and spatial metrics. Journal of the Indian Society of Remote Sensing, 44(4), 617-633. https://doi.org/10.1007/s12524-015-0482-0

Bhatta, B., Saraswati, S., \& Bandyopadhyay, D. (2010). Urban sprawl measurement from remote sensing data. Applied geography, 30(4), 731-740. https://doi.org/10.1016/j.apgeog.2010.02.002

Belal, A. A., \& Moghanm, F. S. (2011). Detecting urban growth using remote sensing and GIS techniques in Al Gharbiya governorate, Egypt. The Egyptian Journal of Remote Sensing and Space Science, 14(2), 73-79. https://doi.org/10.1016/j.ejrs.2011.09.001

Bharath, H. A., Chandan, M. C., Vinay, S., \& Ramachandra, T. V. (2017). Modelling the growth of two rapidly urbanizing Indian cities. Journal of Geomatics, 11(12), 149-166.

Ca L, Li P, Zhang L \& Chen T. (2008). Remote sensing image-based analysis of the relationship between urban heat island and vegetation fraction. The international Archives of Photogrammetry, remote sensing and spatial information sciences, 37.

Cheruto MC, Kauti MK, Kisangau DP, \& Kariuki PC. (2016). Assessment of land use and land cover change using GIS and remote sensing techniques: a case study of Makueni County, Kenya. http://repository.seku.ac.ke/handle/123456789/3062

Chatterjee, N. D., Chatterjee, S., \& Khan, A. (2016). Spatial modeling of urban sprawl around Greater Bhubaneswar city, India. Modeling Earth Systems and Environment, 2(1), 14.

Page $11 / 23$ 
Chettry, V., \& Surawar, M. Assessment of urban sprawl characteristics in Indian cities using remote sensing: case studies of Patna, Ranchi, and Srinagar. Environment, Development and Sustainability, 1-23. https://doi.org/10.1007/s10668-020-01149-3

Dadras, M., Shafri, H. Z., Ahmad, N., Pradhan, B., \& Safarpour, S. (2015). Spatio-temporal analysis of urban growth from remote sensing data in Bandar Abbas city, Iran. The Egyptian Journal of Remote Sensing and Space Science, 18(1), 35-

52. https://doi.org/10.1016/j.ejrs.2015.03.005

Dhali, M. K., Chakraborty, M., \& Sahana, M. (2019). Assessing spatio-temporal growth of urban sub-centre using Shannon's entropy model and principle component analysis: A case from North 24 Parganas, lower Ganga River Basin, India. The Egyptian Journal of Remote Sensing and Space Science, 22(1), 25-35. https://doi.org/10.1016/j.ejrs.2018.02.002

Dadashpoor, H., \& Salarian, F. (2020). Urban sprawl on natural lands: Analyzing and predicting the trend of land use changes and sprawl in Mazandaran city region, Iran. Environment, Development and Sustainability, 22(2), 593-614. https://doi.org/10.1007/s10668-018-0211-2

Fang, S., Gertner, G. Z., Sun, Z., \& Anderson, A. A. (2005). The impact of interactions in spatial simulation of the dynamics of urban sprawl. Landscape and urban planning, 73(4), 294-306. https://doi.org/10.1016/j.landurbplan.2004.08.006

Frenkel, A., \& Ashkenazi, M. (2008). Measuring urban sprawl: how can we deal with it?. Environment and Planning B: Planning and Design, 35(1), 56-79. https://doi.org/10.1068\%2Fb32155

Fertner, C., Jørgensen, G., Nielsen, T. A. S., \& Nilsson, K. S. B. (2016). Urban sprawl and growth management-drivers, impacts and responses in selected European and US cities. Future cities and environment, 2(1), 1-13. https://doi.org/10.1186/s40984-016-0022-2

Fei, W., \& Zhao, S. (2019). Urban land expansion in China's six megacities from 1978 to 2015. Science of The Total Environment, 664, 6071. https://doi.org/10.1016/j.scitotenv.2019.02.008

Gutman G Huang C, Chander G, Noojipady P \& Masek JG. (2013). Assessment of the NASA-USGS global land survey (GLS) datasets. Remote sensing of environment, 134, 249-265.

Gazi MA \& Mondal I. (2018). Urban Heat Island and its effect on Dweller of Kolkata Metropolitan area using geospatial techniques. International Journal of Computer Sciences and Engineering, 6(10), 741-753.

Hassan Z, Shabbir R, Ahmad SS, Malik AH, Aziz N, Butt A \& Erum S. (2016). Dynamics of land use and land cover change (LULCC) using geospatial techniques: a case study of Islamabad Pakistan. Springer Plus, 5(1), 812. https://doi.org/10.1186/s40064-016-2414-z.

Halder B, Banik P \& Bandyopadhyay J. Mapping and monitoring land dynamic due to urban expansion using geospatial techniques on South Kolkata. Saf. Extreme Environ. (2021). https://doi.org/10.1007/s42797-021-00032-2

Inostroza, L., Baur, R., \& Csaplovics, E. (2013). Urban sprawl and fragmentation in Latin America: A dynamic quantification and characterization of spatial patterns. Journal of environmental management, 115, 87-97. https://doi.org/10.1016/j.jenvman.2012.11.007

Ji, W., Ma, J., Twibell, R. W., \& Underhill, K. (2006). Characterizing urban sprawl using multi-stage remote sensing images and landscape metrics. Computers, Environment and Urban Systems, 30(6), 861-879. https://doi.org/10.1016/j.compenvurbsys.2005.09.002

Jensen R, Mausel P, Dias N, Gonser R, Yang C, Everitt J, \& Fletcher R. (2007). Spectral analysis of coastal vegetation and land cover using AISA+ hyperspectral data. Geocarto International, 22(1), 17-28. https://doi.org/10.1080/10106040701204354

Jat, M. K., Garg, P. K., \& Khare, D. (2008). Monitoring and modelling of urban sprawl using remote sensing and GIS techniques. International journal of Applied earth Observation and Geoinformation, 10(1), 26-43. https://doi.org/10.1016/j.jag.2007.04.002

Kadhim, N., Mourshed, M., \& Bray, M. (2016). Advances in remote sensing applications for urban sustainability. Euro-Mediterranean Journal for Environmental Integration, 1(1), 1-22. https://doi.org/10.1007/s41207-016-0007-4

Lu D \& Weng Q. (2006). Use of impervious surface in urban land-use classification. Remote Sensing of Environment, 102(1-2), 146-160. https://doi.org/10.1016/j.rse.2006.02.010

Kumar, J., Biswas, B., \& Walker, S. (2020). Multi-temporal LULC Classification using Hybrid Approach and Monitoring Built-up Growth with Shannon's Entropy for a Semi-arid Region of Rajasthan, India. Journal of the Geological Society of India, 95(6), 626-

635. https://doi.org/10.1007/s12594-020-1489-x

Page 12/23 
Meshesha TW, Tripathi SK. \& Khare D. (2016). Analyses of land use and land cover change dynamics using GIS and remote sensing during 1984 and 2015 in the Beressa Watershed Northern Central Highland of Ethiopia. Modeling Earth Systems and Environment, 2(4), 1-12. https://link.springer.com/article/10.1007/s40808-016-0233-4

Mosammam, H. M., Nia, J. T., Khani, H., Teymouri, A., \& Kazemi, M. (2017). Monitoring land use change and measuring urban sprawl based on its spatial forms: The case of Qom city. The Egyptian Journal of Remote Sensing and Space Science, 20(1), 103-

116. https://doi.org/10.1016/j.ejrs.2016.08.002

MohanRajan, S. N., Loganathan, A., \& Manoharan, P. (2020). Survey on Land Use/Land Cover (LU/LC) change analysis in remote sensing and GIS environment: Techniques and Challenges. Environmental Science and Pollution Research, 27, 29900-

29926. https://doi.org/10.1007/s11356-020-09091-7

Owojori A \& Xie H. (2005, March). Landsat image-based LULC changes of San Antonio, Texas using advanced atmospheric correction and object-oriented image analysis approaches. In 5th international symposium on remote sensing of urban areas, Tempe, AZ.

Ozturk, D. (2017). Assessment of urban sprawl using Shannon's entropy and fractal analysis: a case study of Atakum, Ilkadim and Canik (Samsun, Turkey). Journal of environmental engineering and landscape management, 25(3), 264-

276. https://doi.org/10.3846/16486897.2016.1233881

Punia, M., \& Singh, L. (2012). Entropy approach for assessment of urban growth: a case study of Jaipur, India. Journal of the Indian Society of Remote Sensing, 40(2), 231-244. https://doi.org/10.1007/s12524-011-0141-z

Patra, S., Sahoo, S., Mishra, P., \& Mahapatra, S. C. (2018). Impacts of urbanization on land use/cover changes and its probable implications on local climate and groundwater level. Journal of Urban Management, 7(2), 70-84. https://doi.org/10.1016/j.jum.2018.04.006

Ramachandra, T. V., Bharath, H. A., \& Vinay, S. (2013). Land use land cover dynamics in a rapidly urbanising landscape. SCIT J, 13, 1-12.

Roy DP, Wulder MA, Loveland TR, Woodcock CE, Allen RG, Anderson MC., ... \& Zhu Z. (2014). Landsat-8: Science and product vision for terrestrial global change research. Remote sensing of Environment, 145, 154-172.

Rasul A, Balzter H \& Smith C. (2015). Spatial variation of the daytime Surface Urban Cool Island during the dry season in Erbil, Iraqi Kurdistan, from Landsat 8. Urban climate, 14, 176-186.

Rawat, J. S., \& Kumar, M. (2015). Monitoring land use/cover change using remote sensing and GIS techniques: A case study of Hawalbagh block, district Almora, Uttarakhand, India. The Egyptian Journal of Remote Sensing and Space Science, 18(1), 77-

84. https://doi.org/10.1016/j.ejrs.2015.02.002

Rubiera Morollón, F., González Marroquin, V. M., \& Pérez Rivero, J. L. (2016). Urban sprawl in Spain: differences among cities and causes. European Planning Studies, 24(1), 207-226. https://doi.org/10.1080/09654313.2015.1080230

Rahman, M., Avtar, R., Yunus, A. P., Dou, J., Misra, P., Takeuchi, W., ... \& Agustiono Kurniawan, T. (2020). Monitoring effect of spatial growth on land surface temperature in Dhaka. Remote Sensing, 12(7), 1191. https://doi.org/10.3390/rs12071191

Ramaiah, M., Avtar, R., \& Rahman, M. (2020). Land Cover Influences on LST in Two Proposed Smart Cities of India: Comparative Analysis Using Spectral Indices. Land, 9(9), 292. https://doi.org/10.3390/land9090292

Semenza JC, Rubin CH, Falter KH, Selanikio JD, Flanders WD, Howe HL, \& Wilhelm JL. (1996). Heat-related deaths during the July 1995 heat wave in Chicago. New England journal of medicine, 335(2), 84-90.

Sobrino JA, Raissouni N \& Li ZL. (2001). A comparative study of land surface emissivity retrieval from NOAA data. Remote Sensing of Environment, 75(2), 256-266. https://doi.org/10.1016/S0034-4257(00)00171-1

Sudhira, H. S., Ramachandra, T. V., \& Jagadish, K. S. (2004). Urban sprawl: metrics, dynamics and modelling using GIS. International Journal of Applied Earth Observation and Geoinformation, 5(1), 29-39. https://doi.org/10.1016/j.jag.2003.08.002

Sun, H., Forsythe, W. \& Waters, N. Modeling Urban Land Use Change and Urban Sprawl: Calgary, Alberta, Canada. Netw Spat Econ 7, 353376 (2007). https://doi.org/10.1007/s11067-007-9030-y 
Sarvestani, M. S., Ibrahim, A. L., \& Kanaroglou, P. (2011). Three decades of urban growth in the city of Shiraz, Iran: A remote sensing and geographic information systems application. Cities, 28(4), 320-329. https://doi.org/10.1016/j.cities.2011.03.002

Sandhya Kiran, G., \& Joshi, U. B. (2013). Estimation of variables explaining urbanization concomitant with land-use change: a spatial approach. International Journal of Remote Sensing, 34(3), 824-847. https://doi.org/10.1080/01431161.2012.720738

Scarano M \& Sobrino JA. (2015). On the relationship between the sky view factor and the land surface temperature derived by Landsat-8 images in Bari, Italy. International Journal of Remote Sensing, 36(19-20), 4820-4835.

Srivastava, A., Sahoo, B., Raghuwanshi, N. S., \& Singh, R. (2017). Evaluation of variable-infiltration capacity model and MODIS-terra satellite-derived grid-scale evapotranspiration estimates in a River Basin with Tropical Monsoon-Type climatology. Journal of Irrigation and Drainage Engineering, 143(8), 04017028.

Singh, S. K., Srivastava, P. K., Szabó, S., Petropoulos, G. P., Gupta, M., \& Islam, T. (2017). Landscape transform and spatial metrics for mapping spatiotemporal land cover dynamics using Earth Observation data-sets. Geocarto international, 32(2), 113127. https://doi.org/10.1080/10106049.2015.1130084

Sahani, S., \& Raghavaswamy, V. (2018). Decoding patterns of urban dynamics in class-1 city of khammam, Telangana State, India. Journal of the Indian Society of Remote Sensing, 46(5), 749-759. https://doi.org/10.1007/s12524-017-0718-2

Sisodia, P. S., Tiwari, V., \& Dahiya, A. K. (2018). Urban sprawl monitoring using remote sensing and GIS techniques of the city Jaipur, India. In E-Planning and Collaboration: Concepts, Methodologies, Tools, and Applications (pp. 716-728). IGI Global.

Sahana, M., Hong, H., \& Sajjad, H. (2018). Analyzing urban spatial patterns and trend of urban growth using urban sprawl matrix: A study on Kolkata urban agglomeration, India. Science of the Total Environment, 628, 1557-1566. https://doi.org/10.1016/j.scitotenv.2018.02.170

Shukla, A., \& Jain, K. (2019). Modeling urban growth trajectories and spatiotemporal pattern: a case study of Lucknow City, India. Journal of the Indian Society of Remote Sensing, 47(1), 139-152. https://doi.org/10.1007/s12524-018-0880-1

Shooshtari, S. J., Silva, T., Namin, B. R., \& Shayesteh, K. (2020). Land use and cover change assessment and dynamic spatial modeling in the Ghara-su Basin, Northeastern Iran. Journal of the Indian Society of Remote Sensing, 48(1), 81-95. https://doi.org/10.1007/s12524-01901054-x

Tewolde, M. G., \& Cabral, P. (2011). Urban sprawl analysis and modeling in Asmara, Eritrea. Remote Sensing, 3(10), 21482165. https://doi.org/10.3390/rs3102148

USGS (2001) Landsat Science Data User's handbooks https://www.usgs.gov/land-resources/nli/landsat/landsat- 8-data-users-handbook Verzosa, L. C. O., \& Gonzalez, R. M. (2010). Remote sensing, geographic information systems and Shannon's entropy: Measuring urban sprawl in a mountainous environment.

Vani, M., \& Prasad, P. R. C. (2020). Assessment of spatio-temporal changes in land use and land cover, urban sprawl, and land surface temperature in and around Vijayawada city, India. Environment, Development and Sustainability, 22(4), 3079-

3095. https://doi.org/10.1007/s10668-019-00335-2

Weng Q \& Lo CP. (2001). Spatial analysis of urban growth impacts on vegetative greenness with Landsat TM data. Geocarto international, 16(4), 19-28.

Weber, C., \& Puissant, A. (2003). Urbanisation pressure and modelling of urban growth: Example of the Tunis Metropolitan Area. Remote Sensing of Environment, 86(3), 341-352.

Wu, Y., Li, S., \& Yu, S. (2016). Monitoring urban expansion and its effects on land use and land cover changes in Guangzhou city, China. Environmental monitoring and assessment, 188(1), 54.

Xiao H \& Weng Q. (2007). The impact of land use and land cover changes on land surface temperature in a karst area of China. Journal of environmental management, 85(1), 245-257.

Yeh, A. G. O., \& Li, X. (2001). Measurement and monitoring of urban sprawl in a rapidly growing region using entropy. Photogrammetric engineering and remote sensing, 67(1), 83-90.

Page 14/23 
Yu X, Guo X \& Wu Z. (2014). Land surface temperature retrieval from Landsat 8 TIRS-Comparison between radiative transfer equationbased method, split window algorithm and single channel method. Remote sensing, 6(10), 9829-9852.

\section{Tables}

Table 1 Details of data acquisition.

\begin{tabular}{llccc}
\hline Satellite & Sensor & Date & Path \& Row & Data Source \\
\hline Landsat 5 & TM & $14-11-1990$ & 138,44 & https://earthexplorer.usgs.gov/ \\
& & $26-01-2000$ & 138,44 & \\
\cline { 1 - 3 } Landsat 8 & OLI/TIRS & $06-02-2010$ & 138,44 & \\
\cline { 3 - 4 } & & $18-12-2020$ & 138,44 & \\
\hline
\end{tabular}

Table 2 Descriptions of each land use and land cover classes.

\begin{tabular}{cll}
\hline Sl No. & LULC classes & \multicolumn{1}{c}{ Description } \\
\hline 1 & Built-up Area & Residential area, commercial area, industrial area, transportations, roads and construction area. \\
2 & Thick Vegetation & Area having plantation or natural growing forest, its including many types of trees, open vegetated area. \\
\hline 3 & Open Space & These types of classes are mainly playground, open area and many others. \\
\hline 4 & Water Bodies & River, Pond, lakes, and open water bodies. \\
\hline 5 & Agricultural Land & Crop land and fallow land of this area. \\
6 & Wet Land & The substrate is nonsoil and covered shallow water \\
\hline 7 & Grass Land & Grasses area and scatter vegetation. \\
\hline
\end{tabular}

Table 3 Scale of kappa coefficient.

\begin{tabular}{cll}
\hline Sl No. & Value of $\mathrm{K}$ & Strength of agreement \\
\hline 1 & $<0.20$ & Poor \\
2 & $0.21-0.40$ & Fair \\
\hline 3 & $0.41-0.60$ & Moderate \\
\hline 4 & $0.61-0.80$ & Good \\
\hline 5 & $0.81-1.00$ & Very good \\
\hline
\end{tabular}

Table 4 Area calculation of different LULC classes and percentage of classes.

\begin{tabular}{lrrrrrrrr}
\hline \multicolumn{1}{c}{ Class Name } & \multicolumn{4}{c}{ Area (Sq.km) } & \multicolumn{4}{c}{ Area (\%) } \\
\cline { 2 - 9 } & 1990 & 2000 & 2010 & 2020 & 1990 & 2000 & 2010 & 2020 \\
\hline Water Body & 2.15 & 7.29 & 6.95 & 5.58 & 0.76 & 2.59 & 2.47 & 1.99 \\
\hline Open Space & 10.52 & 8.42 & 7.52 & 5.84 & 3.74 & 2.99 & 2.68 & 2.07 \\
\hline Grassland & 19.72 & 17.29 & 15.72 & 13.53 & 7.02 & 6.15 & 5.59 & 4.81 \\
\hline Thick Vegetation & 95.73 & 92.05 & 88.03 & 77.74 & 34.07 & 32.76 & 31.33 & 27.66 \\
\hline Agricultural Land & 142.66 & 137.41 & 131.24 & 124.85 & 50.77 & 48.9 & 46.71 & 44.44 \\
\hline Built-up Land & 10.22 & 18.54 & 31.54 & 53.46 & 3.64 & 6.6 & 11.22 & 19.02 \\
\hline Total & 281 & 281 & 281 & 281 & 100 & 100 & 100 & 100 \\
\hline
\end{tabular}

Table 5 Difference in area of different years. 


\begin{tabular}{ccccc}
\hline Class Name & $\begin{array}{c}\text { Difference in Area } \\
(1990-2000)\end{array}$ & $\begin{array}{c}\text { Difference in Area } \\
(2000-2010)\end{array}$ & $\begin{array}{c}\text { Difference in Area } \\
(2010-2020)\end{array}$ & $\begin{array}{c}\text { Difference in Area } \\
(1990-2020)\end{array}$ \\
\hline Water Body & 5.14 & -0.34 & -1.37 & 3.43 \\
\hline Open Space & -2.1 & -0.9 & -1.68 & -4.68 \\
Grassland & -2.43 & -1.57 & -2.19 & -6.19 \\
$\quad \begin{array}{c}\text { Thick } \\
\text { Vegetation }\end{array}$ & -3.68 & -4.02 & -10.29 & -17.99 \\
$\begin{array}{c}\text { Agricultural } \\
\text { Land }\end{array}$ & -5.25 & -6.17 & -6.39 & -17.81 \\
\hline \begin{tabular}{c} 
Built-up Land \\
\hline
\end{tabular} & 8.32 & 13 & 21.92 & 43.24 \\
\hline
\end{tabular}

Table 6 Quadrant-wise and overall distribution of Shannon's entropy value (1990-2020).

\begin{tabular}{cccccccccc}
\hline Year & \multicolumn{8}{c}{ Quadrants } & \multirow{2}{*}{ Overall En Value } \\
\cline { 2 - 9 } & $\mathrm{N}$ & NE & E & SE & S & SW & W & NW & \\
\hline 1990 & 0.20 & 0.20 & 0.21 & 0.21 & 0.24 & 0.20 & 0.20 & 0.18 & 0.28 \\
2000 & 0.22 & 0.24 & 0.22 & 0.24 & 0.28 & 0.20 & 0.20 & 0.20 & 0.34 \\
\hline 2010 & 0.24 & 0.26 & 0.40 & 0.22 & 0.28 & 0.24 & 0.20 & 0.20 & 0.40 \\
\hline 2020 & 0.34 & 0.34 & 0.48 & 0.30 & 0.38 & 0.28 & 0.28 & 0.24 & 0.48 \\
\hline
\end{tabular}

Table 7 Distribution of built-up density from the CBD to the periphery area.

\begin{tabular}{|c|c|c|c|c|c|c|}
\hline \multirow[t]{2}{*}{ Sl No. } & \multirow[t]{2}{*}{ Name of Buffer Zones } & \multirow[t]{2}{*}{ Distance of Buffer ring from CBD $(\mathrm{km})$} & \multicolumn{4}{|c|}{ Percentage of Built-up area } \\
\hline & & & 1990 & 2000 & 2010 & 2020 \\
\hline 1 & CBD & 1 & 10.88 & 19.33 & 42.04 & 79.52 \\
\hline 2 & Core area & 2 & 4.25 & 5.24 & 36.18 & 49.24 \\
\hline 3 & Outer core area & 3 & 2.27 & 2.98 & 28.75 & 26.79 \\
\hline 4 & Urban fringe area & 4 & 1.98 & 2.25 & 22.65 & 14.68 \\
\hline 5 & Thresholds urban limit area & 5 & 1.75 & 1.94 & 10.58 & 10.87 \\
\hline 6 & Periphery area & 6.5 & 0.67 & 0.92 & 09.65 & 5.94 \\
\hline
\end{tabular}

Table 8 Accuracy assessment and kappa coefficient in the year of 1990.

\begin{tabular}{|c|c|c|c|c|c|c|c|c|c|c|}
\hline \multirow[t]{2}{*}{ Class Name } & \multicolumn{7}{|c|}{ Ground Truth/Reference } & \multirow{2}{*}{$\begin{array}{l}\text { Row } \\
\text { Total }\end{array}$} & \multirow{2}{*}{$\begin{array}{c}\text { Commission } \\
\text { Error }\end{array}$} & \multirow{2}{*}{$\begin{array}{c}\text { User } \\
\text { Accuracy }\end{array}$} \\
\hline & $\begin{array}{l}\text { Water } \\
\text { Body }\end{array}$ & $\begin{array}{l}\text { Wet } \\
\text { Land }\end{array}$ & $\begin{array}{l}\text { Open } \\
\text { Space }\end{array}$ & Grassland & $\begin{array}{l}\text { Thick } \\
\text { Vegetation }\end{array}$ & $\begin{array}{l}\text { Agricultural } \\
\text { Land }\end{array}$ & $\begin{array}{l}\text { Built-up } \\
\text { land }\end{array}$ & & & \\
\hline Water Body & 25 & 1 & 1 & 0 & 0 & 1 & 0 & 28 & $10.71 \%$ & $89.29 \%$ \\
\hline Wet Land & 1 & 23 & 0 & 1 & 0 & 0 & 0 & 25 & $8.00 \%$ & $92.00 \%$ \\
\hline Open Space & 0 & 1 & 33 & 2 & 0 & 1 & 0 & 37 & $10.81 \%$ & $89.19 \%$ \\
\hline Grassland & 0 & 0 & 1 & 29 & 1 & 0 & 0 & 31 & $6.45 \%$ & $93.55 \%$ \\
\hline $\begin{array}{l}\text { Thick } \\
\text { Vegetation }\end{array}$ & 0 & 1 & 2 & 2 & 90 & 2 & 1 & 98 & $8.16 \%$ & $91.84 \%$ \\
\hline $\begin{array}{l}\text { Agricultural } \\
\text { Land }\end{array}$ & 1 & 0 & 0 & 1 & 2 & 99 & 1 & 104 & $4.81 \%$ & $95.19 \%$ \\
\hline $\begin{array}{l}\text { Built-up } \\
\text { land }\end{array}$ & 1 & 0 & 0 & 0 & 0 & 1 & 41 & 43 & $4.65 \%$ & $95.35 \%$ \\
\hline $\begin{array}{l}\text { Column } \\
\text { Total }\end{array}$ & 28 & 26 & 37 & 35 & 93 & 104 & 43 & 366 & & \\
\hline $\begin{array}{l}\text { Omission } \\
\text { Error }\end{array}$ & $10.71 \%$ & $11.54 \%$ & $10.81 \%$ & $17.14 \%$ & $3.23 \%$ & $4.81 \%$ & $4.65 \%$ & & & \\
\hline $\begin{array}{l}\text { Produce } \\
\text { Accuracy }\end{array}$ & $89.29 \%$ & $88.46 \%$ & $89.19 \%$ & $82.86 \%$ & $96.77 \%$ & $95.19 \%$ & $95.35 \%$ & & & \\
\hline $\begin{array}{l}\text { Overall } \\
\text { Accuracy }\end{array}$ & $92.90 \%$ & & & & $\begin{array}{l}\text { Kappa } \\
\text { Coefficient }\end{array}$ & 0.91 & & & & \\
\hline
\end{tabular}

Table 9 Accuracy assessment and kappa coefficient in the year of 2000. 


\begin{tabular}{|c|c|c|c|c|c|c|c|c|c|c|}
\hline \multirow[t]{2}{*}{ Class Name } & \multicolumn{7}{|c|}{ Ground Truth/Reference } & \multirow{2}{*}{$\begin{array}{l}\text { Row } \\
\text { Total }\end{array}$} & \multirow{2}{*}{$\begin{array}{l}\text { Commission } \\
\text { Error }\end{array}$} & \multirow{2}{*}{$\begin{array}{c}\text { User } \\
\text { Accuracy }\end{array}$} \\
\hline & $\begin{array}{l}\text { Water } \\
\text { Body }\end{array}$ & $\begin{array}{l}\text { Wet } \\
\text { Land }\end{array}$ & $\begin{array}{l}\text { Open } \\
\text { Space }\end{array}$ & Grassland & $\begin{array}{l}\text { Thick } \\
\text { Vegetation }\end{array}$ & $\begin{array}{l}\text { Agricultural } \\
\text { Land }\end{array}$ & $\begin{array}{l}\text { Built- } \\
\text { up } \\
\text { land }\end{array}$ & & & \\
\hline Water Body & 31 & 2 & 1 & 0 & 0 & 0 & 0 & 35 & $8.57 \%$ & $88.57 \%$ \\
\hline Wet Land & 1 & 24 & 1 & 1 & 0 & 0 & 0 & 27 & $11.11 \%$ & $88.89 \%$ \\
\hline Open Space & 0 & 0 & 33 & 2 & 1 & 1 & 0 & 37 & $10.81 \%$ & $89.19 \%$ \\
\hline Grassland & 1 & 0 & 1 & 29 & 2 & 1 & 0 & 34 & $14.71 \%$ & $85.29 \%$ \\
\hline $\begin{array}{l}\text { Thick } \\
\text { Vegetation }\end{array}$ & 2 & 1 & 2 & 2 & 114 & 3 & 1 & 125 & $8.80 \%$ & $91.20 \%$ \\
\hline $\begin{array}{l}\text { Agricultural } \\
\text { Land }\end{array}$ & 0 & 0 & 0 & 1 & 2 & 138 & 1 & 142 & $2.82 \%$ & $97.18 \%$ \\
\hline $\begin{array}{l}\text { Built-up } \\
\text { land }\end{array}$ & 1 & 0 & 2 & 0 & 0 & 1 & 49 & 53 & $7.55 \%$ & $92.45 \%$ \\
\hline $\begin{array}{l}\text { Column } \\
\text { Total }\end{array}$ & 36 & 27 & 40 & 35 & 119 & 144 & 51 & 453 & & \\
\hline $\begin{array}{l}\text { Omission } \\
\text { Error }\end{array}$ & $13.89 \%$ & $11.11 \%$ & $17.50 \%$ & $17.14 \%$ & $4.20 \%$ & $4.17 \%$ & $3.92 \%$ & & & \\
\hline $\begin{array}{l}\text { Produce } \\
\text { Accuracy }\end{array}$ & $86.11 \%$ & $88.89 \%$ & $82.50 \%$ & $82.86 \%$ & $95.80 \%$ & $95.83 \%$ & $96.08 \%$ & & & \\
\hline $\begin{array}{l}\text { Overall } \\
\text { Accuracy }\end{array}$ & $92.27 \%$ & & & & & $\begin{array}{l}\text { Kappa } \\
\text { Coefficient }\end{array}$ & 0.9 & & & \\
\hline
\end{tabular}

Table 10 Accuracy assessment and kappa coefficient in the year of 2010.

\begin{tabular}{|c|c|c|c|c|c|c|c|c|c|c|}
\hline \multirow[t]{2}{*}{ Class Name } & \multicolumn{7}{|c|}{ Ground Truth/Reference } & \multirow{2}{*}{$\begin{array}{l}\text { Row } \\
\text { Total }\end{array}$} & \multirow{2}{*}{$\begin{array}{c}\text { Commission } \\
\text { Error }\end{array}$} & \multirow{2}{*}{$\begin{array}{c}\text { User } \\
\text { Accuracy }\end{array}$} \\
\hline & $\begin{array}{l}\text { Water } \\
\text { Body }\end{array}$ & $\begin{array}{l}\text { Wet } \\
\text { Land }\end{array}$ & $\begin{array}{l}\text { Open } \\
\text { Space }\end{array}$ & Grassland & $\begin{array}{l}\text { Thick } \\
\text { Vegetation }\end{array}$ & $\begin{array}{l}\text { Agricultural } \\
\text { Land }\end{array}$ & $\begin{array}{l}\text { Built-up } \\
\text { land }\end{array}$ & & & \\
\hline Water Body & 40 & 1 & 1 & 1 & 0 & 0 & 0 & 43 & $6.98 \%$ & $93.02 \%$ \\
\hline Wet Land & 1 & 32 & 1 & 0 & 0 & 0 & 0 & 34 & $5.88 \%$ & $94.12 \%$ \\
\hline Open Space & 0 & 1 & 25 & 2 & 0 & 1 & 0 & 29 & $13.79 \%$ & $86.21 \%$ \\
\hline Grassland & 1 & 0 & 1 & 34 & 1 & 0 & 0 & 38 & $7.89 \%$ & $89.47 \%$ \\
\hline $\begin{array}{l}\text { Thick } \\
\text { Vegetation }\end{array}$ & 0 & 0 & 1 & 1 & 147 & 2 & 1 & 152 & $3.29 \%$ & $96.71 \%$ \\
\hline $\begin{array}{l}\text { Agricultural } \\
\text { Land }\end{array}$ & 0 & 1 & 0 & 1 & 2 & 119 & 2 & 125 & $4.80 \%$ & $95.20 \%$ \\
\hline $\begin{array}{l}\text { Built-up } \\
\text { land }\end{array}$ & 0 & 1 & 1 & 0 & 1 & 2 & 41 & 46 & $10.87 \%$ & $89.13 \%$ \\
\hline $\begin{array}{l}\text { Column } \\
\text { Total }\end{array}$ & 42 & 36 & 30 & 39 & 151 & 124 & 44 & 467 & & \\
\hline $\begin{array}{l}\text { Omission } \\
\text { Error }\end{array}$ & $4.76 \%$ & $11.11 \%$ & $16.67 \%$ & $12.82 \%$ & $2.65 \%$ & $4.03 \%$ & $6.82 \%$ & & & \\
\hline $\begin{array}{l}\text { Produce } \\
\text { Accuracy }\end{array}$ & $95.24 \%$ & $88.89 \%$ & $83.33 \%$ & $87.18 \%$ & $97.35 \%$ & $95.97 \%$ & $93.18 \%$ & & & \\
\hline $\begin{array}{l}\text { Overall } \\
\text { Accuracy }\end{array}$ & $93.79 \%$ & & & & & $\begin{array}{l}\text { Kappa } \\
\text { Coefficient }\end{array}$ & 0.92 & & & \\
\hline
\end{tabular}

Table 11 Accuracy assessment and kappa coefficient in the year of 2020. 


\begin{tabular}{|c|c|c|c|c|c|c|c|c|c|c|}
\hline \multirow[t]{2}{*}{ Class Name } & \multicolumn{7}{|c|}{ Ground Truth/Reference } & \multirow{2}{*}{$\begin{array}{l}\text { Row } \\
\text { Total }\end{array}$} & \multirow{2}{*}{$\begin{array}{c}\text { Commission } \\
\text { Error }\end{array}$} & \multirow{2}{*}{$\begin{array}{c}\text { User } \\
\text { Accuracy }\end{array}$} \\
\hline & $\begin{array}{l}\text { Water } \\
\text { Body }\end{array}$ & $\begin{array}{l}\text { Wet } \\
\text { Land }\end{array}$ & $\begin{array}{l}\text { Open } \\
\text { Space }\end{array}$ & Grassland & $\begin{array}{l}\text { Thick } \\
\text { Vegetation }\end{array}$ & $\begin{array}{l}\text { Agricultural } \\
\text { Land }\end{array}$ & $\begin{array}{l}\text { Built-up } \\
\text { land }\end{array}$ & & & \\
\hline Water Body & 39 & 2 & 1 & 0 & 0 & 0 & 0 & 42 & $7.14 \%$ & $92.86 \%$ \\
\hline Wet Land & 2 & 52 & 1 & 2 & 0 & 1 & 0 & 58 & $10.34 \%$ & $89.66 \%$ \\
\hline Open Space & 0 & 1 & 42 & 1 & 0 & 1 & 0 & 45 & $6.67 \%$ & $93.33 \%$ \\
\hline Grassland & 0 & 1 & 1 & 49 & 0 & 0 & 0 & 52 & $3.85 \%$ & $94.23 \%$ \\
\hline $\begin{array}{l}\text { Thick } \\
\text { Vegetation }\end{array}$ & 0 & 0 & 1 & 1 & 157 & 2 & 1 & 162 & $3.09 \%$ & $96.91 \%$ \\
\hline $\begin{array}{l}\text { Agricultural } \\
\text { Land }\end{array}$ & 1 & 1 & 1 & 1 & 2 & 167 & 2 & 175 & $4.57 \%$ & $95.43 \%$ \\
\hline $\begin{array}{l}\text { Built-up } \\
\text { land }\end{array}$ & 1 & 2 & 2 & 0 & 1 & 1 & 91 & 98 & $7.14 \%$ & $92.86 \%$ \\
\hline $\begin{array}{l}\text { Column } \\
\text { Total }\end{array}$ & 43 & 59 & 49 & 54 & 160 & 172 & 94 & 632 & & \\
\hline $\begin{array}{l}\text { Omission } \\
\text { Error }\end{array}$ & $9.30 \%$ & $11.86 \%$ & $14.29 \%$ & $9.26 \%$ & $1.88 \%$ & $2.91 \%$ & $3.19 \%$ & & & \\
\hline $\begin{array}{l}\text { Produce } \\
\text { Accuracy }\end{array}$ & $90.70 \%$ & $88.14 \%$ & $85.71 \%$ & $90.74 \%$ & $98.13 \%$ & $97.09 \%$ & $96.81 \%$ & & & \\
\hline $\begin{array}{l}\text { Overall } \\
\text { Accuracy }\end{array}$ & $94.46 \%$ & & & & & $\begin{array}{l}\text { Kappa } \\
\text { Coefficient }\end{array}$ & 0.93 & & & \\
\hline
\end{tabular}

Figures

(70,0


Figure 1

Location map of this study area.

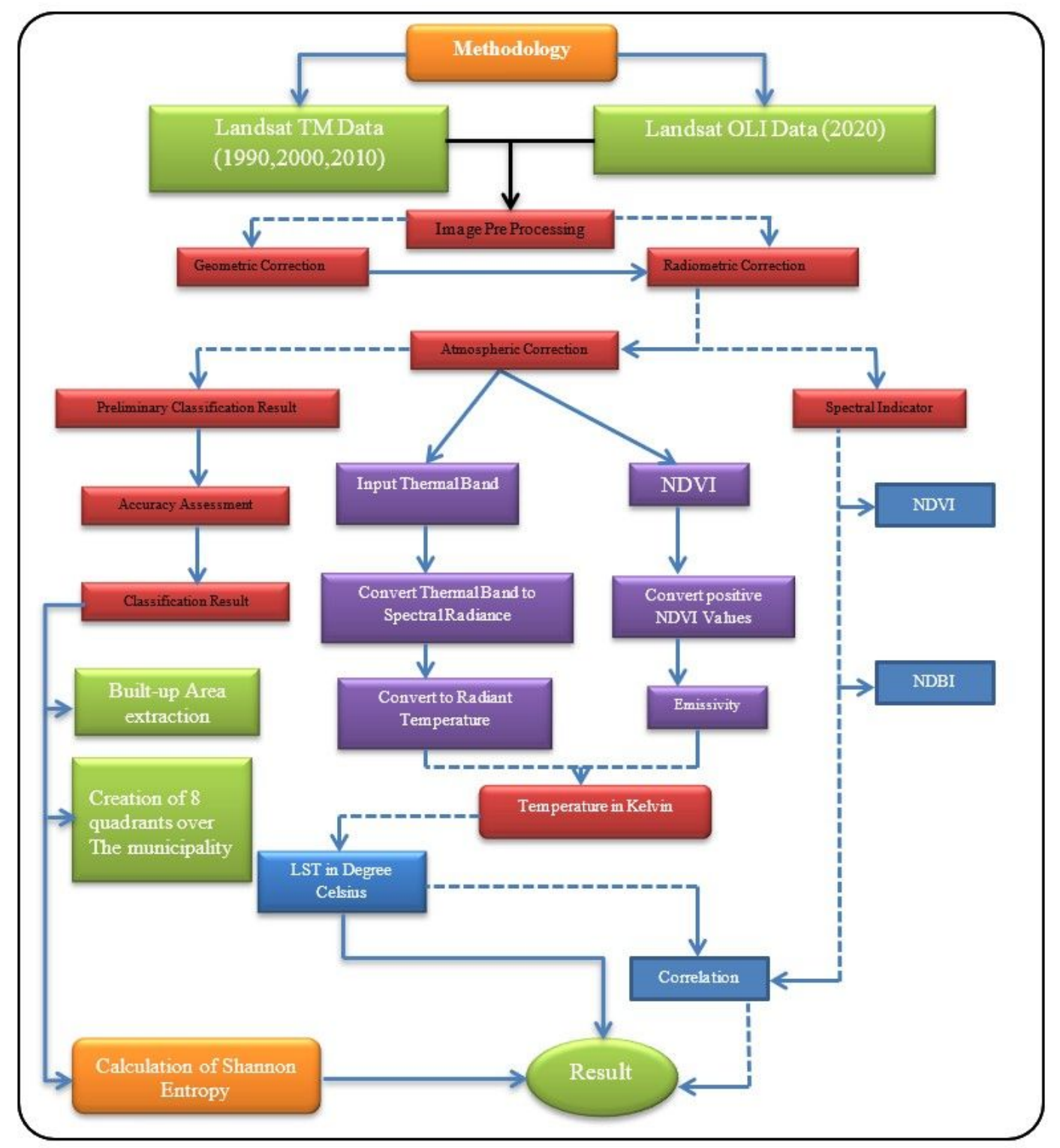

Figure 2

Methodology of entire study. 


\begin{tabular}{|c|c|c|c|c|c|c|c|}
\hline $8^{\circ} 32^{\prime} \mathrm{E}$ & $8^{\circ} 36^{\prime} \mathrm{E}$ & $88^{\circ} 40^{\prime} \mathrm{E}$ & $8^{\circ} 44^{\prime} \mathrm{E}$ & $8^{\circ} 32^{\prime}$ E & $8^{\circ} 36^{\prime} \mathrm{E}$ & $8^{\circ} 40^{\prime} \mathrm{E}$ & $8^{\circ} 44^{\prime} \mathrm{E}$ \\
\hline$\Lambda^{N}$ & $x^{-1}+4$ & 1990 & $+2 \pi t^{\text {(a) }}$ & $\bigwedge^{N}$ & 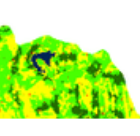 & 2000 & (b) \\
\hline
\end{tabular}

\section{Figure 3}

Land use and land cover map of different years (1990-2020). 


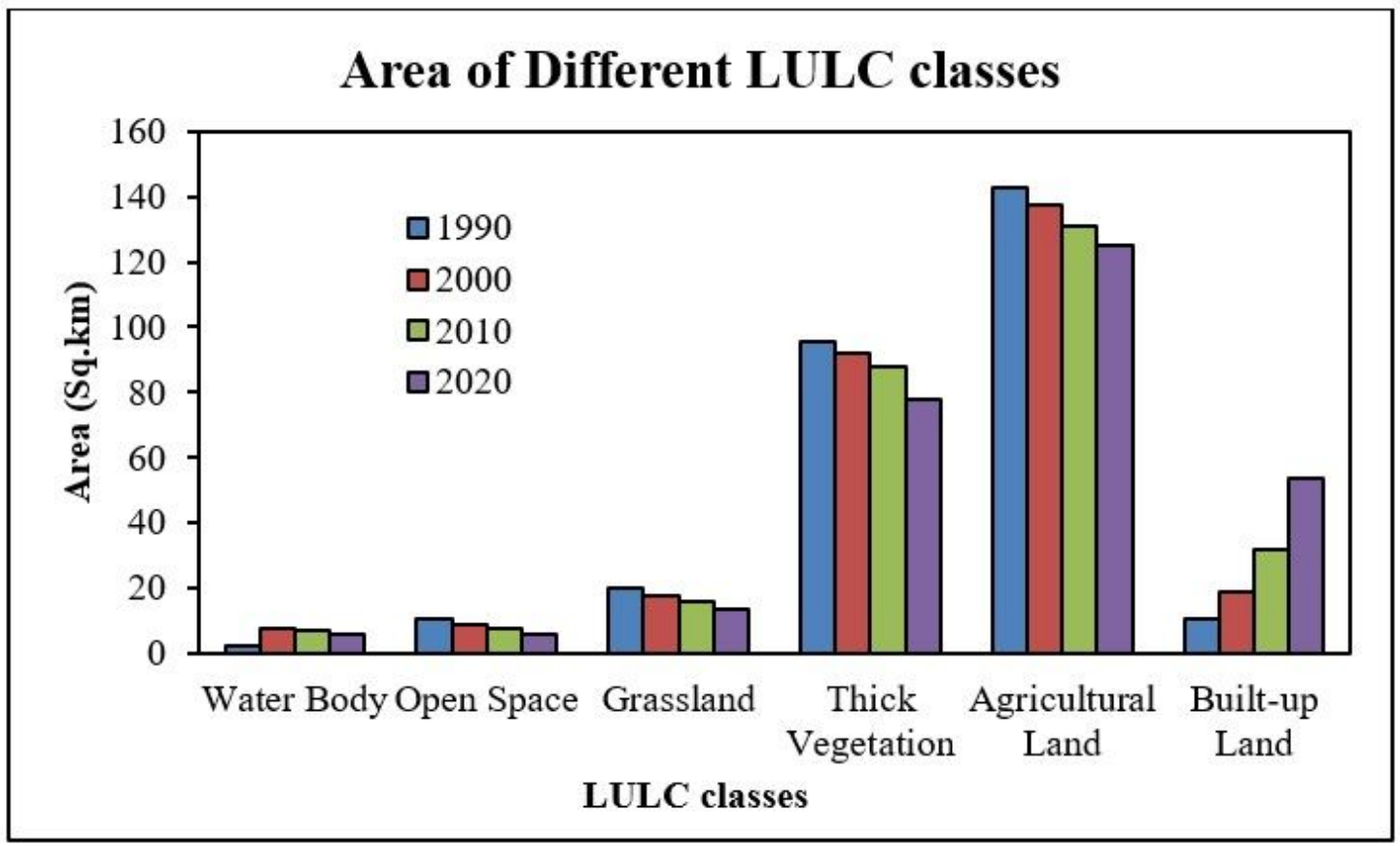

Figure 4

Area of each class in different year's interval. 

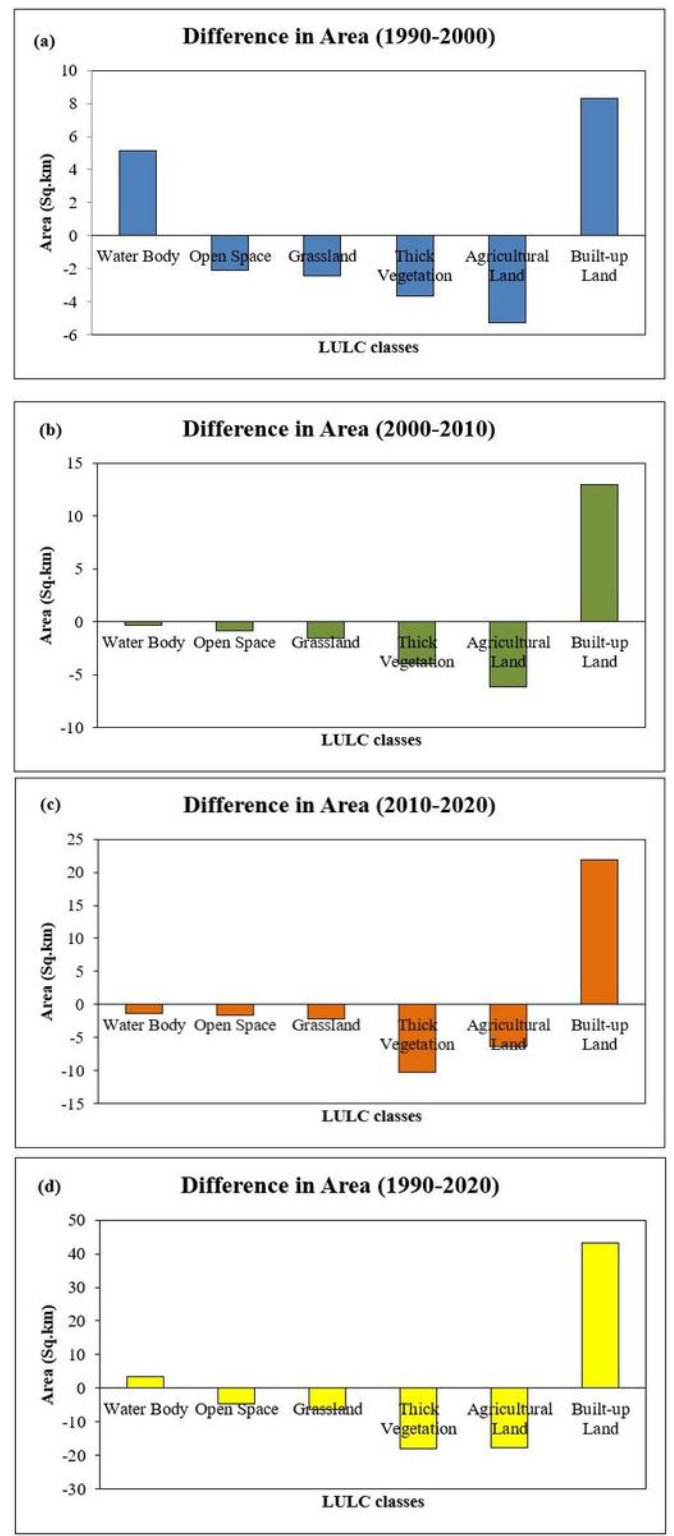

\section{Figure 5}

Gain/loss of LULC in different years. (a) Difference in area (1990-2000); (b) Difference in area (2000-2010); (c) Difference in area (20102020); and Difference in area (1990-2020).

\section{Figure 6}

Quadrant-wise division for Shannon's entropy calculation in different years (1990-2020).

\section{Figure 7}

Division of buffer zones for measuring built-up density. 


\section{Figure 8}

Land surface temperature (LST) maps of different years interval.

\section{Figure 9}

NDVI maps of different years interval (1990-2020).

\section{Figure 10}

NDBI maps of different years interval (1990-2020).

\section{Figure 11}

Correlation-ship with LST and different spectral indicators (NDVI and NDBI)of different time intervals (1990-2020). 